\title{
Fused Silica as Solid Support for Artificial Protease Exploiting Aldehyde and Histidine as Catalytic Groups
}

\author{
Myoung-soon Kim, In Seok Hong, ${ }^{\dagger}$ Hyunsook Kim, Hyesun Paik, Yeon-Sook Chung, and Junghun Suh ${ }^{\dagger}$ \\ School of Chemistrv and Center for Molecular Catalvis. Seoul Vational Wniversitv Seoul 151-747, Korea \\ -Artzime Biotech Corporation, t01-3 Silim-1-dong, Seoul 151-012. Korea \\ Recened December 9, 2002
}

Key Words : Artificial enz̧'me. Fused silica. Proteolysis

Previously, we reported synthesis of effective artificial proteases by attaching aldehyde and other organic functional groups to silica gel. ${ }^{1}$ As illustrated by $1 / 2$. the aldelyde group was proposed to act as a binding site by forming an inine with the anino group of the protein substrate. Polar groups $\mathrm{X}$ and $\mathrm{Y}-\mathrm{H}$ can act as nucleophiles. general bases, or general acids. $\mathrm{X}$ and $\mathrm{Y}-\mathrm{H}$ may include aldehyde hydrate. carboxylic acid. alcohol. thiol. phenol, and imidazole as well as their ionized forms. When the extra functional group attached to the aldehyde-containing silica gel was inidazole. the artificial protease hydrolyzed ovalbumin $(\mathrm{Ovl})$, albumin (Alb). hemoglobin (Hgb), and $\gamma$ globulin (Gbn) with halflives as short as $50 \mathrm{~min}$ at $25^{\circ} \mathrm{C}$ or $7 \mathrm{~min}$ at $50^{\circ} \mathrm{C}$
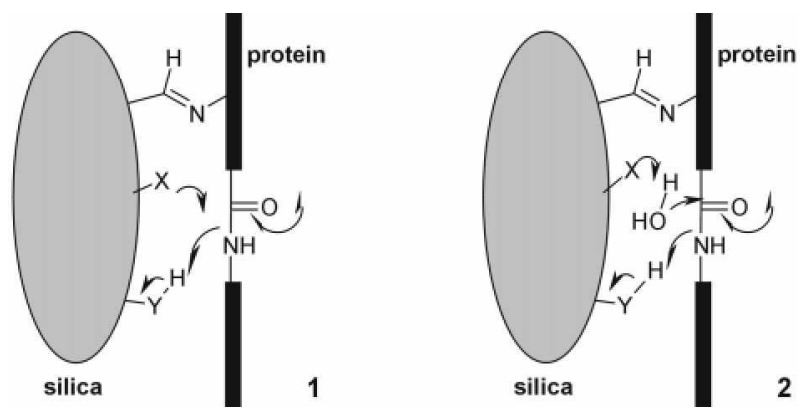

For the synthesis of the artificial proteases, the silica surface was covered with primary amino groups by reacting silica with $\gamma$-aminopropyltriethoxysilane (APS). It is reported that the reaction of APS with the silanol hydroxyl groups located on the surface of silica gel forms the silica derivative with structure indicated by $\mathrm{Si}(\mathrm{A})$ or $\mathrm{Si}(\mathrm{B})$ predominantly under anhydrous or hydrous conditions, respectively. ${ }^{2.3}$ In the previous study, APS was attached to silica gel under anhydrous conditions to form $\mathrm{Si}(\mathrm{A}){ }^{1}$ The most effective catalyst obtained in the previous study contained both aldehyde groups and histidine moieties attached to the silica surface by the synthetic route illustrated in Scheme $1 .^{1}$ For example. catalyst $\mathrm{Si}(\mathrm{A})-\mathrm{G}_{-51}-\mathrm{His}_{22}-\mathrm{G}_{16}-\mathrm{His}_{10}$ was synthesized by repeating the attaclument of glutaraldelyde and histidine whereas catalyst $\mathrm{Si}(\mathrm{A})-\mathrm{G}_{170}-\mathrm{His}_{3,5}-\mathrm{G}_{36}-\mathrm{His}_{3}-\mathrm{Ac}_{70}$ was prepared by acetylation of $\mathrm{Si}(\mathrm{A})-\mathrm{G}_{170}-\mathrm{His}_{3,-}-\mathrm{G}_{36}-\mathrm{His}_{3}$. In the names of the cataly sts prepared in the previous and the present studies. the subscript numbers (\#) stand for the amount of glutaraldehyde $(\mathrm{G})$ or histidine (His) in terms of mol \% relative to the anino group of $\mathrm{Si}(\mathrm{A})$. $\mathrm{Si}(\mathrm{B})$. or $\mathrm{Si}(\mathrm{C})$.

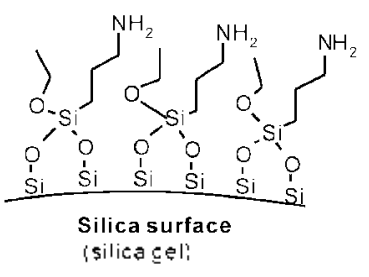

$\operatorname{Si}\{A\}$

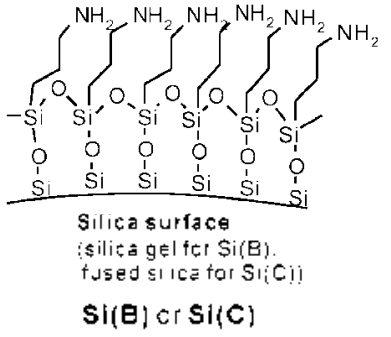

Protein substrates have molecular weights usually exceeding $10 \mathrm{kDa}$. Most of the aldehyde groups or histidine moieties attached to silica gel would not be accessible to such large molecules. Only the functional groups positioned in open areas on the silica surface would act as catalytic groups in degradation of proteins and, possibly, even oligopeptides.

Fused silica is much cheaper (less than $\$ 1 / \mathrm{kg}$ ) than silica gel. Unlike the functional groups attached to silica gel. most of the catalytic groups attached to fused silica would be accessible to large molecules. Thus, fused silica could be utilized as a more econonical solid support for artificial proteases. In the present study. we attached glutaraldehyde and histidine to fused silica and compared the proteolytic activity of the resulting catalyst with those built on silica gel.

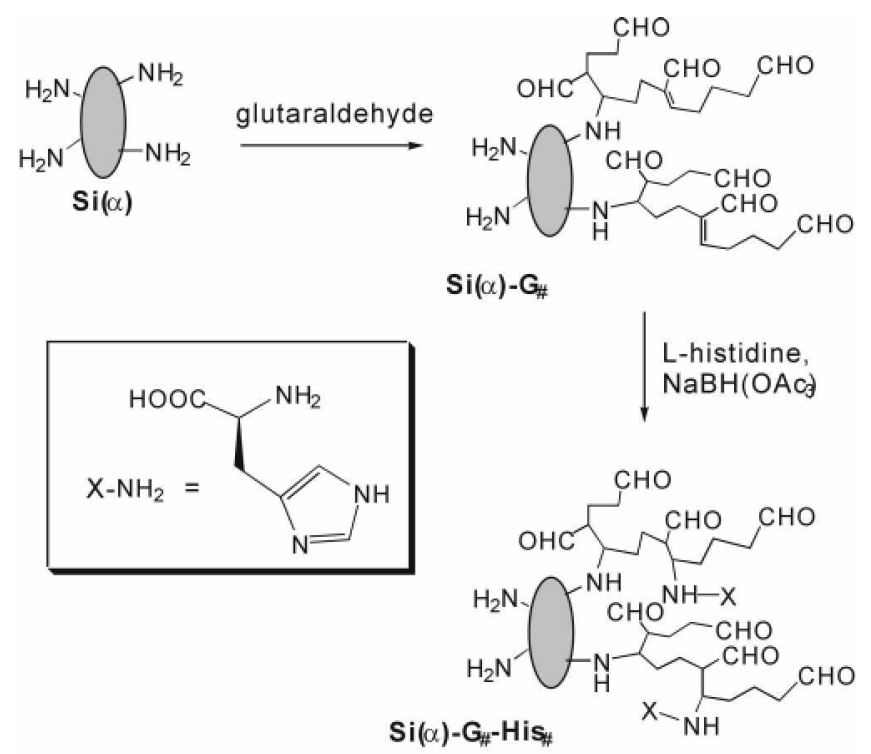

Scheme 1 
Fused silica particles were treated with acid to release silanol hydroxyl groups on the surface. ${ }^{+}$The silica sufface was subsequently covered with primary amino groups by reacting with APS in the presence of water to obtain $\mathrm{Si}(\mathrm{C})$. It was hoped that the content of amino groups can be raised by reacting silica with APS under hydrous conditions. Silica gel was also treated under hydrous conditions to obtain $\mathrm{Si}(\mathrm{B})$. The content of amino groups in $\mathrm{Si}(\mathrm{B})$ was estimated by elemental analysis. The contents of pendants attached to the surface of fused silica were too low to estimate by elemental analysis. The content of primary anino group in $\mathrm{Si}(\mathrm{C})$ was. therefore, estimated colorimetrically by Kaiser test using ninhydrin. The contents of anines in $\mathrm{Si}(\mathrm{B})$ and $\mathrm{Si}(\mathrm{C})$ were $2.1 \mathrm{mmol} / \mathrm{g}$ and $0.17 \mu \mathrm{mol} / \mathrm{g}$, respectively. whereas that in $\mathrm{Si}(\mathrm{A})$ prepared in the previous work was $1.3 \mathrm{mmol} / \mathrm{g}$. Assuming that the population of silanol hydroxyl groups on silica surface is 4.55 residues $/ \mathrm{nm}^{2}$ as reported ${ }^{6}$ in the literature and the fused silica particles are spherical with diameter of $0.1 \mathrm{~nm}$ and density of $2.21 \mathrm{~g} / \mathrm{mL}$. the amount of silanol hydroxyl group present on the surface of fused silica is estimated as $0.21 \mu \mathrm{mol} / \mathrm{g}$. The surface of silica gel appears to be about $10^{+}$-times greater than that of fised silica.

Attaclment of glutaraldehyde and histidine to $\mathrm{Si}(\mathrm{B})$ and $\mathrm{Si}(\mathrm{C})$ was carried out according to Scheme $\mathrm{I}$ as reported previously. ${ }^{1.7}$ Two new cataly sts were prepared: $\mathrm{Si}(\mathrm{B})-\mathrm{G}_{1 \mathrm{ta} \mathrm{C}^{-}}$ $\mathrm{His}_{16}$ and $\mathrm{Si}(\mathrm{C})$-G-His $\mathrm{S}_{25}$. The contents of glutaraldehyde and histidine in $\mathrm{Si}(\mathrm{B})-\mathrm{G}_{1+10}-\mathrm{His}_{16}$ were estimated by elemental analysis as reported previously. ${ }^{1.7} \mathrm{Si}(\mathrm{C})-\mathrm{G}$ and $\mathrm{Si}(\mathrm{C})-\mathrm{G}-\mathrm{His}_{2} \mathrm{~s}$ were treated with $m$-xylenediamine and $\mathrm{NaBH}(\mathrm{OAc})_{3}$ in tetrahydrofuran for $12 \mathrm{~h}$ and the amount of primary amines introduced were estimated by Kaiser test. The content of His in $\mathrm{Si}(\mathrm{C})$-G-His 2 was calculated from the difference in the amount of the primary anines thus introduced. assuning that introduction of $m$-xylenediamine to $\mathrm{Si}(\mathrm{C})-\mathrm{G}-\mathrm{His}_{2} \mathrm{~s}$ was blocked by the histidine residue.

Chicken egg Ovl (M.W. $44 \mathrm{kDa}$ ). bovine serum Alb (M.W. $66 \mathrm{kDa}$ ), bovine serum Gbn (M.W. $150 \mathrm{kDa}$ ). and bovine $\mathrm{Hgb}$ (M.W. $62 \mathrm{kDa}$ ) were tested as substrate proteins. Rates for cleavage of the proteins by the silica-based cataly sts were measured by following disappearance of parent bands in SDS-PAGE electrophoresis as described previously. ${ }^{7-12}$ The two chains of Gbn have distinctly different molecular weights $(25 \mathrm{kDa}$ and $50 \mathrm{kDa}$ ) and rates for their disappearance were separately measured. On the other hand the two subunits of
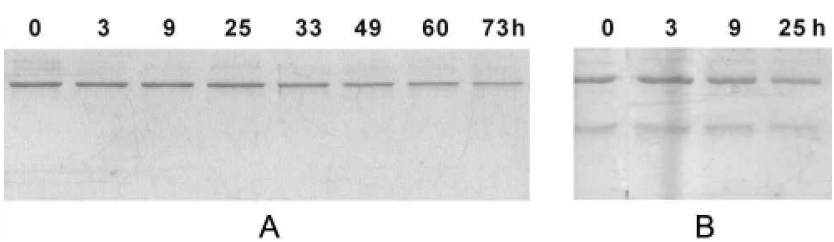

Figure 1. Results of SDS-PAGE obtained with Alb (a) or the heavy (upper band) and light (lower band) chains of Gbrn (b) incubated with $\mathrm{Si}(\mathrm{C})-\mathrm{G}-\mathrm{His}_{15}$ at $50^{\circ} \mathrm{C}$ and $\mathrm{pH} 6.0$.

$\mathrm{Hgb}$ have similar molecular weights ( $15 \mathrm{kDa}$ and $16 \mathrm{kDa})$. and, therefore. disappearance of the combined band of the two subunits was followed. Examples of the electrophoretic results are illustrated in Figure 1

Pseudo-first-order kinetic behavior was observed for degradation of protein substrates in the presence of the artificial proteases under the conditions indicated in Table 1. The pseudo-first-order rate constants $\left(k_{\mathrm{c}}\right)$ were little affected by the shaking speed as far as the shaking speed exceeded $600 \mathrm{rpm}$. The kinetic measurements were performed at the shaking speed of $1200 \mathrm{rpm}$ as described previously. ${ }^{1.7}$ The kinetic data measured for degradation of protein substrates by the catalysts are summarized in Table $\mathrm{l}$.

The fused silica-based catalyst, $\mathrm{Si}(\mathrm{C})$-G-His ${ }_{25}$, is closely related to the silica gel-based catalyst, $\mathrm{Si}(\mathrm{B})-\mathrm{G}_{1+i}-\mathrm{His}_{16}$, as both of them were obtained by treatment with APS under hydrous conditions and by introduction of histidine in one step. The catalytic activity of $\mathrm{Si}(\mathrm{C})$-G-His is toward the four protein substrates is about $7.50 \%$ of that of $\mathrm{Si}(\mathrm{B}) \cdot \mathrm{G}_{1+i \mathrm{i}}-\mathrm{His}_{16}$. This difference stands in marked contrast with the about $10^{4}$ fold difference in the content of amino, aldehyde. and histidyl groups of the two catalysts. Fused silica is much cheaper than silica gel. About $10^{+}$-times greater amounts of APS. glutaraldelyde and histidine are needed for the synthesis of $\mathrm{Si}(\mathrm{B})-\mathrm{G}_{140}-\mathrm{His}_{16}$ compared with that of $\mathrm{Si}(\mathrm{C})-\mathrm{G}-$ $\mathrm{His}_{25}$. In spite of the large difference in the cost and materials needed to synthesize the catalysts, only minor difference is observed for their proteoly tic activities.

Results of the present study indicate that fused silica can be used as an economical solid support for immobile catalysts using macromolecules as reactants or catalysts. Proteins are used as substrates in the present study. but many enzymes are linked to solid supports to obtain inmobilized enzymes. Fused silica can be also exploited as an economical solid support for immobilized enzymes.

Table 1. Values of $k_{o}\left(10^{-2} \mathrm{~m}^{-1}\right)$ for hydrolytic cleavage of various proteins by silica-based artificial proteases ${ }^{n}$

\begin{tabular}{|c|c|c|c|c|}
\hline Catalyst ${ }^{b}$ & Ovl & Alb & $\mathrm{Hgb}$ & Gbn \\
\hline 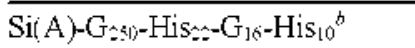 & $1.2(6)^{*}$ & $1.1(9)$ & $1.1(7)^{*}$ & $1.3(9) * / 0.96(8)^{*}$ \\
\hline $\left.\mathrm{Si}(\mathrm{A})-\mathrm{G}_{(>1)-\mathrm{His}}-\mathrm{G}_{36}-\mathrm{His}_{3}-\mathrm{Ac}=1\right)^{5}$ & $0.76(6)^{*}$ & $0.81(7)$ & $1.2(8)^{*}$ & $0.73(8) / 0.52(8)$ \\
\hline $\mathrm{Si}(\mathrm{B})-\mathrm{G}_{14 i ;}-\mathrm{His}_{16}$ & $0.97(5)$ & $1.3(7)$ & $3.3(7)$ & $1.2(7) / 1.4(8)$ \\
\hline $\mathrm{Si}(\mathrm{C})-\mathrm{G}-\mathrm{His} \_\underline{\underline{s}}$ & $0.51(6)$ & $0.21(7)$ & $0.22(8)$ & $0.11(7) / 0.13(8)$ \\
\hline
\end{tabular}

"Kinetic measurements were performed with $100 \mathrm{mg}$ of catalyst added to $1.5 \mathrm{~mL}$ of $0.05 \mathrm{M}$ butfer solution containing $0.15 \mathrm{mg}$ of the protein substrate. Values of $k$ were measured at the optimum $\mathrm{pH}$ indicated in parentheses and at $50^{\circ} \mathrm{C}$ except those marked with * which were measured at $25^{\circ} \mathrm{C}$. Relative standard deviations of $k$, were $10 \cdot 25^{\circ} \mathrm{v}$. For Gbn. $k_{\text {s }}$ values for the heavy and the light chains are indicated in sequence with put between them. Possibility that disappearance of the parent protein was due to adsorption onto the silica was excluded by the method' described previously: 'Taken from ref. 1 


\section{Experimental Section}

Catalysts. Fused silica (particle size: 0.044-0.149 mm. density: $2.21 \mathrm{~g} / \mathrm{mL}$ ), purchased from Boran Chenical Co. was treated with $\mathrm{HCl}$ and $\mathrm{H}_{2} \mathrm{SO}_{4}$ according to the literature. ${ }^{+}$ The acid-treated fused silica was treated with APS under hydrous conditions to obtain $\mathrm{Si}(\mathrm{C})$. according to the method reported in the literature. ${ }^{, 3} \mathrm{Si}(\mathrm{C})$-G-His ${ }_{25}$ was obtained by shaking $\mathrm{Si}(\mathrm{C})(50 \mathrm{~g})$ in a buffer $(\mathrm{pH} 7.5 .10 \mathrm{mM}$ phosphate: $250 \mathrm{~mL}$ ) containing $5 \%(\mathrm{v} / \mathrm{v})$ glutaraldehyde for $2 \mathrm{~h}$ at the shaking speed of $200 \mathrm{rpm}$ followed by shaking the resulting $\mathrm{Si}(\mathrm{C}) \cdot \mathrm{G}(15 \mathrm{~g})$ with $\mathrm{L}-\mathrm{His}(12 \mathrm{~mm} / \mathrm{l})$ and $\mathrm{NaBH}(\mathrm{OAc})_{3}(25$ $\mu \mathrm{mol})$ dissolved in the Mes buffer $(100 \mathrm{~mL})$ for $2 \mathrm{~d}$ at $25^{\circ} \mathrm{C}$. Silica gel was treated with APS under hydrous conditions to obtain $\mathrm{Si}(\mathrm{B})$. which was modified to obtain $\mathrm{Si}(\mathrm{B})-\mathrm{G}_{1+4)}-\mathrm{His}_{16}$ according to the procedure reported previously.'

Measurements. Ovl. Alb, Gbn. and $\mathrm{Hgb}$ were purchased from Signa. For kinetic measurements, the reaction mixtures were shaken in a heated shaking incubator (a VorTemp 56 model). Psendo-first-order rate constants were calculated from the intensities of electrophoretic bands of the protein substrate measured at various time intervals. Intensities of electrophoretic bands were estimated with an AlphaImager ${ }^{\mathrm{TM}}$ IS- 1220 model

Acknowledgment. This work was supported by Center for Molecular Catalysis and Artzyme Biotech Corporation. M.-s. K., H. K., H. P., and Y.-S. C. were recipients of BK2l fellowship.

\section{References}

1. Kim. H; Kim. M.-s; Paik. H: Chung. Y.-S.: Hong. I; Suh, J. Bioorg. Hed. Chem. Lett 2002, 12,3247.

2. Vansant, E. F; van der Voort. P; Vrancken, K. C. In Characterization and Chemical Hodification of the Silica Suface: Elsevier: Amsterdam. 1995: pp 175-180.

3. Vranken. K. C.: van der Voort. P.: Possemier. K.: Van1sant. E. F. $J$ Colloid Interfac. Sci. 1995. 174, 86.

4. Chrisey, L. A.: Lee, G. U.; OFerrall. C. E. Nucleic Acids Res. 1996. 24, 3031 .

5. Sarin. V. K.: Kent. S. B. H.: Tam. J. P.: Merritield. R. B. Anal. Biochem. 1981. 117. 147.

6. Peri. T. B.: Hensley. A. L. J. Phos Chem. 1968. 72. 2926.

7. Kim, H.: Paik. H.: Kim. M.-s.: Chung. Y.-S.: Suh, J. Bioorg Med. Chem. Lett. $2002,12.2557$

8. Suh, J Hah, S. S. J. Am. Chem. Soc. 1998. 120. 10088.

9. Jan1g. B.-B.: Lee. K. P.: Minl. D. H.: Sul1. I. J. Am. Chem. Soc. 1998. 120.12008

10. On. S.: Chang. W.: Sulh. T. Bioorg. Med Chem. Lett 2001. 1 . 1469.

11. Suh, J:-Oh, S. J. Org Chem 2000, 65, 7534

12. Kim, H.: Chung, Y.S.: Paik, H.: Kim, M.-s.: Suh, J. Bioong, Med. Chem. Lett. 2002. 12. 2663 